UNITED STATES DEPARTMENT OF THE INTERIOR

Harold L. Ickes, Secretary

GEOLOGICAL SURVEY

W. C. Mendenhall, Director

Bulletin 931-J

\title{
QUICKSILVER DEPOSITS IN THE STEENS AND PUEBLO MOUNTAINS SOUTHERN OREGON
}

BY

CLYDE P. ROSS

Strategic Minerals Investigations, 1941

(Pages 227-258)

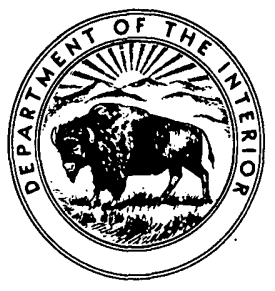

UNITED STATES

GOVERNMENT PRINTING OFFICE

WASHINGTON : 1942

\footnotetext{
For sale by the Superintendent of Documents, Washington, D. C. - - - - - Price 40 cents
} 



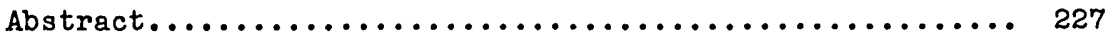

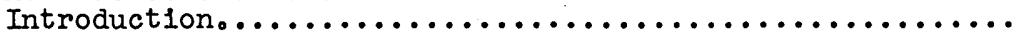

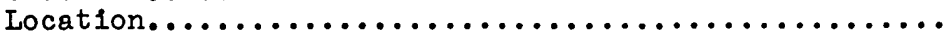

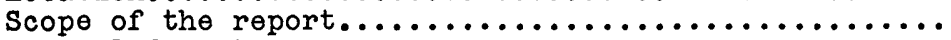

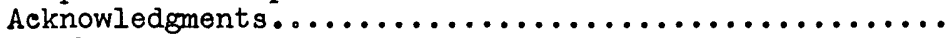

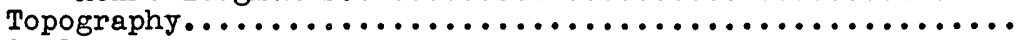

Geology......................................

Pre-Tertiary rocks.........................

Age..................................

Tertiary volcanic rocks.....................

Age....................................

older alluvium............................

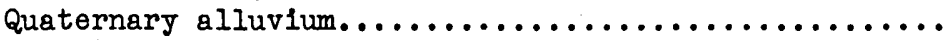

structure.................................

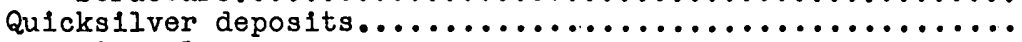

Mineralogy................................

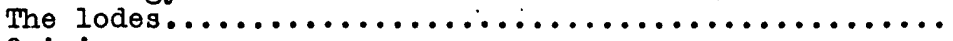

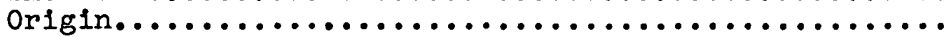

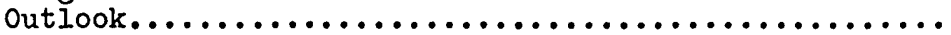

Prospects...................................

Steens Mountain prospect....................

Flsher group............................

Lucky strike and adjacent prospects................

Clalms near Sesena Creek.......................

The Red King group...........................

The Rabbit Hole group.........................

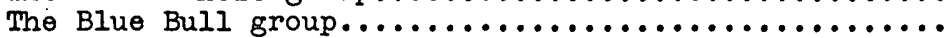

Arlzona mine............................

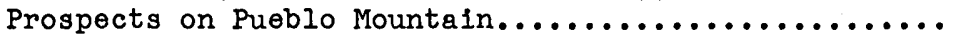

Plate 39. Geologic sketch map of parts of the steens and Pueblo Mountains, Harney County,

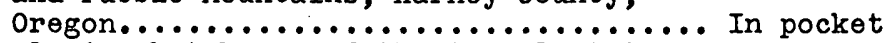
40. Geolog1c sketch map of the tunnel at the

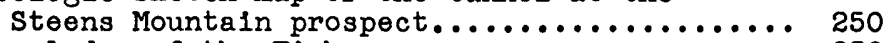

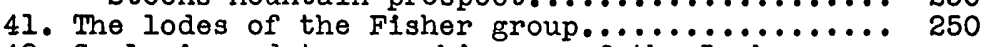

42. Geologic and topographic map of the Lucky Strike group and adjacent ground.......... 254

43. The lodes on the Mogul, Blalr, and 0 Keefe

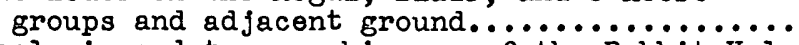

44. Geologic and topographic map of the Rabbit Hole and Red King prospects near Flelds, Oregon...

Figure 23. Index map of Oregon, showing the location of the Steens and Pueblo Mountains............ 



\section{QUICKSILVER DEPOSITS IN THE}

\section{STEENS AND PUEBLO MOUNTAINS, SOUTHERN OREGON}

By Clyde P. Ross

\section{ABSTRACT}

The steens and Pueblo mountain ranges together form a shallow crescent of northerly trend in the eastern part of Harney County, oreg. They contain more than 15 quicksilver prospects and a few that were opened for gold and copper. Most of the area is underlain by flexed and faulted Tertiary lava, but pre-. Tertlary metamorphic and 1gneous rocks are exposed in the southern part. Part of the eastern flank of the mountains consists of somewhat deformed alluvial deposits, whlch are younger than the lava but older than the lacustrine and alluvial deposits on the valley floors.

The lavas along the east side of the mountains have undergone rather extensive hydrothermal alteration. At intervals for a distance of about $30 \mathrm{miles}$ they contain mineralized fracture zones, in most of which mercurlal tetrahedrite and cinnabar are the principal valuable minerals. The pre-Tertiary rocks in the southern part of the mountains also contain lodes: These were first explored for gold and copper, but locally they contain quicksilver as well.

Although the presence of quicksilver deposits in the steens and Pueblo Mountains has been known for 40 years, they have been very little explored and probably less than 10 flasks of quicksilver has been produced from them. The lodes on the whole are of low grade, although they contain rich pockets, some of which may have formed in the zone of weathering. The low average tenor, coupled with the large size of some of the lodes and the metallurgical problems introduced by the unusual mineralogy, suggest that the area may be better adapted to exploration by large, well-equipped organizations than to working by individual operators. If keen demand for quicksilver continues, this region should be considered as a possible source of supply.

\section{INTRODUCTION}

\section{Location}

The Steens and Pueblo Mountains, in eastern Harney County, oreg., together form an essentially continuous range, resembling 
a shallow crescent in plan, which extends from near the $43^{\circ}$ parallel of latitude almost due south past the Oregon-Nevada boundary, which is the $42^{\circ}$ parallel (f1g. 23). This part of Oregon is a sparsely settled region, devoted to stock raising. The supply centers are Burns, Oreg., and Winnemucca, Nev. The princlpal settlements close to the prospects are Andrews, Flelds, and Denio. The last-named, which is at the State boundary, is by far the largest of the three. According to the 1940 census,

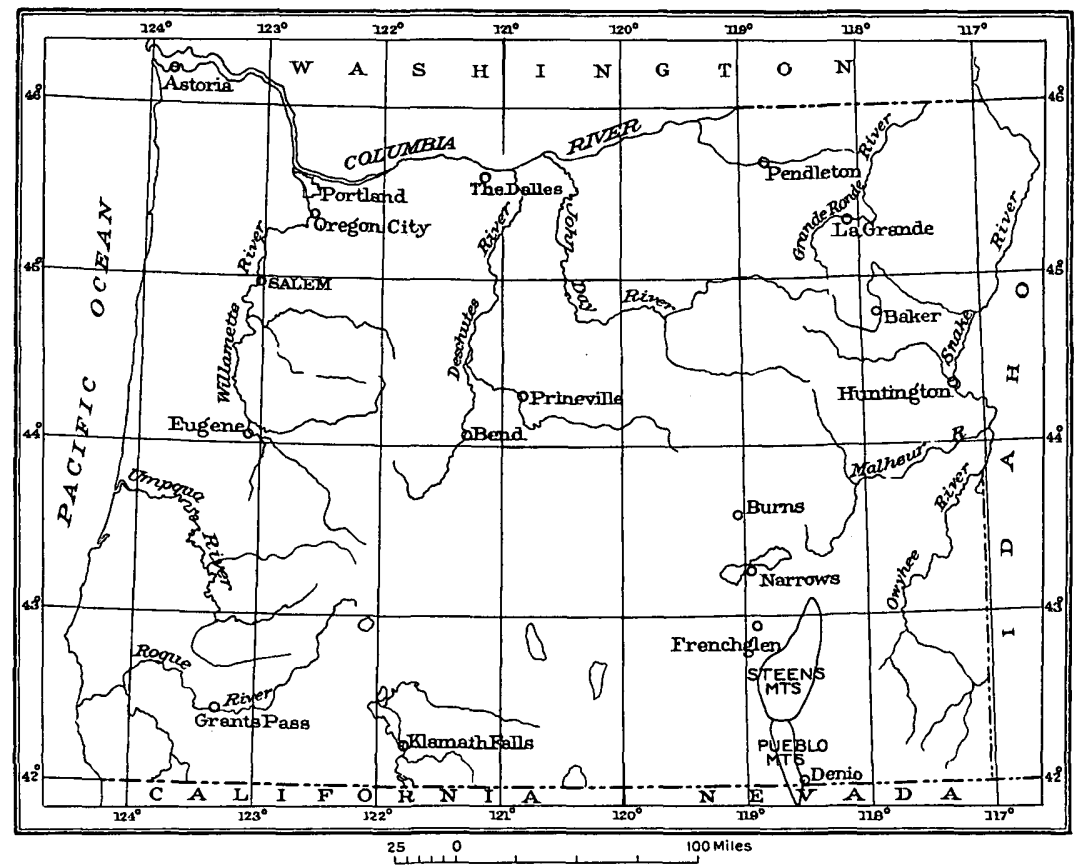

\section{Plforre 23.--Index map of Oregon, showing the location of the Steens and Problo Mountrins.}

the Denlo precinct contains 158 people and the Andrews precinct 125, but most of these live at scattered ranches in Alvord Valley.

Denio is about a hundred miles from Winnemucca, Nev., by a road which is partly paved and partly surfaced with gravel. From Denio to Fields there is a dirt road, about $23 \mathrm{mlles}$ long, that is easily passable in dry weather. From fields one road, approximately 118 miles long, extends across the mountains to 
the west and goes through Frenchglen and Narrows to Burns. Another, roughly $134 \mathrm{miles}$ long, passes along the east front of the mountains through Andrews to Burns. Both roads are unimproved except near Burns. The prospects can all be reached or closely approached by automobile along branch roads passable in dry weather.

\section{Scope of the report}

During the summer of 1940, 34 days were spent in a preliminary study of the quicksilver deposits in the Steens and Pueblo Mountains. Nearly all of the quicksllver prospects were examIned and mapped, and the general geology of the east flank of the mountains from north of Andrews to Denio was reconnoltered.

Alrplane photographs of most of the area in the two mountain ranges were made by the Aero Service Corporation of Philadelphia for use in the geologic field work, and these form the principal basis for the sketch map of the region (see pl. 39), as well as for plates 41 and 43. The township plats issued by the General Land office and other published information were also used in compling plate 39. As the photographs were not individually adfusted to control, and few section corners were 1dentified, plate 39 is only approximately correct.

\section{Acknowledgments}

The whole-hearted cooperation extended by those interested In the quicksilver deposits of the region is deeply appreciated. Cecil Doan and A. 0. Bartell were especially helpful, but everyone encountered during the fleld work gave assistance and information freely. Herman zwang assisted efficiently in the fleld work. The cooperation of J. J. Fahey, who made the chemical analyses, of F. C. Calkins, H. G. Ferguson, C. S. Ross, and other members of the Geological survey has been Indispensable. 


\section{TOPOGRAPHY}

The Steens and Puebio Mountains together form a sinuous range about 90 miles long, about half of which is included in the present reconnalssance. The Steens Mountains, with a maximum width of 25 miles, rise in gentle slopes cut by steep canyons on the west, but on the east they break off in a series of cliffs and steep slopes. The ragged crest line culminates in Steens Mountain $(9,354$ feet), which is north of the area shown In plate 39. The crest descends rather abmuptly northward and more gradually southward. Alvord Peak, near the southern end of the range, is about 7,100 feet above sea level.' The pass between the steens and Pueblo ranges has an elevation of roughly 5,500 feet.

The central part of the Steens Mountains is so rugged that it is unsettled and rarely visited, a fact which may account for the scarcity of prospects there. No prospects were reported to the writer in the mountains north of Bone Canyon except the Steens Mountain prospect and a few others near 1t. All of them are close to the northern border of the area shown in plate 39. Some of the comparatively low and easily accessible ridges at the southern end of the steens Mountains, on the contrary, are thickly dotted with prospect holes.

The Pueblo Mountains are a topographic and structural continuation of the Steens Mountains. They are lower but broken into a number of ridges. On the west, gentle, partly dissected slopes rise to a fairly even, sinuous crest. The northern part of this crest has elevations close to 7,000 feet, but about 15 miles south of the pass utilized by the road from fields to Frenchglen and Burns, the mountains are more rugged and rise to elevations of over 8,000 feet. East of the northern part of the crest there is a precipitous descent to a dissected upland bench dotted with cuesta-like hills. A number of ranches and camps are scattered on and along the margins of this bench, and pros- 
pects are falrly plentiful near its eastern border. The stream valleys on the bench are shallow but most of them become fairly steep-walled as they plunge eastward to die out near the border of Alvord Valley. From near fields to Arizona Creek the eastern border of the mountain consists of smooth-surfaced spurs trendIng roughly perpendicular to the edge of Alvord Valley. These spurs are composed of such porous material that the streamways carry little water past them in dry weather. Most of the spurs end eastward in low bluffs, but some merge with modern alluvial cones.

South of Arizona Creek the east side of the mountain is relatively rocky and steep. This part of the range culminates in Pueblo Mountain (8,550 feet), which crowns a ridge more than 2 miles east of the crest of the main range. Some of the streams in this part of the range carry water during much of the jear. Steep, winding roads extend well up the eastern slope of Pueblo Mountain, in part to serve the gold, copper, and quicksilver prospects there.

East of the higher part of the steens Mountains lies the compound, nearly level Alvord Valley, about 4,000 feet above sea level. The valley is nearly 35 miles wide and contains the playa known as Alvord Desert. In dry weather the wind commonly keeps great clouds of fine dust in circulation. At times these clouds reach heights of over a mile above the level of the desert. Alvord Lake, a little farther south in the same valley, retains some water for much of the year. South of this lake the valley is in places only a few miles wide. Borax was formerly quarried 1 from deposits south of Alvord Lake. Tum Tum Lake, near the southern end, dries up in the summer. Stock ranches are dotted over the valley wherever water is available.

\footnotetext{
1) Waring, G. A., Geology and water resources of the Harney Basin region, Oregon: U. S. Geol. Surver Hater-Supply Paper 231, p. 72, 1909.
} 


\section{GEOLOGY}

\section{$\underline{\text { Pre-Tertiary rocks }}$}

The rocks beneath the Tertiary lavas are exposed only in the southern part of the region. In the present investigation they were seen at only two localities, one in the vicinity of the prospects high on the east slopes of Pueblo Mountain and near Arlzona Creek, and the other close to the main road from north of Colony Creek to Denio. At the first locality these older rocks are mainly greenstone and associated sedimentary beds, 10cally schistose; at the second locality they are mainly white, much-weathered sericite schist. About a mile and a half northeast of Denio there are outcrops of somewhat gneissic granitic rock. The part of the Pueblo Mountains that extends south into Nevada contains, according to Blake, limestones and micaceous and talcose schists.

Age.--No direct evidence as to the age of the old rocks was obtained, but they are obviously much older than the Tertiary volcanic rocks. Analogy with more thoroughly studied rocks in neighboring parts of Nevada $3 /$ suggests that the stratified rocks are of Paleozo1c, possibly Carboniferous, age, and that the granitic rocks may have been intruded near the end of the Jurassic. Some support for these assumptions is afforded by the fact that limestone in the Pine Forest Range, just south of the Pueblo Mountains, has yielded round crinold stems that may be Carboniferous. 4

\section{Tertiary volcanic rocks}

The steens and Pueblo mountain ranges consist mainly of volcanlc rocks. Within the area of plate 39 these include repre-

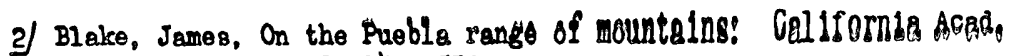
Sc1. Proc., vol. 5, pp. 210-214, 1873.

3/ Ferguson, B. G.. personal communication.

4) Merrtam, J. C., Tertiary mamnal beds of Virein Valley and Thousand Creek, In northwestern Nevada: Cellfornia Univ., Dept. Cool. Sc1., Bull. 6. pp. 29-30, 1910 .
} 
sentatives of the units described by Fuller $5 /$ as the Pike Creek volcanic serles, the Steens Mountain andesitic serles, and the Steens Mountain, or, as it is now called, the steens basalt. It is not possible at present to separate the three units on plate 39.

The gray to lavender rock at the Steens Mountain prospect tunnel belongs to the part of Fuller's Pike Creek serles that he regards as the sites of vents through which the lava reached the surface. It has fine laminations which vary in attitude within short distances but are generally inclined at angles of $60^{\circ}$ to $85^{\circ}$. This rock is thoroughly sillcifled but may be an altered glassy rhyolite. A short distance above the tunnel a light purple dacite is exposed that has closely spaced, nearly vertical parting planes but is not banded. East of the tunnel are thinly banded, steeply inclined rhyolites, locally containing abundant spherulites.

The volcanic rocks in the Steens and Pueblo Mountains south of the locality just described are mainly basalts and andesitic lavas, although other rocks are present in places. The aggregate thickness has not been measured but is several thousand feet. The flows exposed in the vicinity of prospects along the east side of the Pueblo Mountains and in the southern end of the Steens Mountalns include several kinds of porphyritic and amygdaloldal lavas with some flow brecclas. The dashed portions of the contacts on plate 39 are based mainly on interpretation of alrplane photographs, supported by distant observations. In the northern part of the area shown on this map no photographs are avaliable for most. of the mountain border and at no place do the photographs extend east of the western edge of Alvord Valley.

5/ Fuller, R. I., The geomorphology and rolcanic sequence of Steens Mountain In southeastern Oregon: Mashington Un1v. [Seattle] Pub. in GooloE7, vol. 3. No. 1, pp. 57-121, 1931.

6] Plper, A, M., Rob1nson, T. M., and Park, C. P., Jr., Goology and ground-water resources of the Harneg Basin, Oregons U. S. Geol. Survey Nater-Supply Paper 841, pp. 49-50, 1939. 
Geologic boundaries and other features in these parts of plate 39 are consequently based on townshlp plats, supplemented by Waring's geologic map.

The andesites are purple and brownish rocks consisting mainly of plagioclase embedded in devitrifled glass with small amounts of dark minerals, which are altered beyond recognition in the material studied. The plagloclase ranges in composition in different flows from oligoclase to calcic andesine. Some of the flows contain amygdules filled mainly with zeolites and quartz. Magnetite in tiny grains is widely distributed throughout the rock, and hematite and hydrous iron oxides provide the principal coloring matter in the altered flows. Clay, silica, and iron oxide minerals formed by hydrothermal alteration are widespread in the lavas and are similar to those described by Fuller $7 /$ in areas farther north. The effects of alteration are especially intense in the vicinity of the quicksilver lodes. Some of the rock in and near the lodes is altered beyond recognition.

The basalt flows are black to dark brown. Some flows contain abundant large labradorite phenocrysts, but most of them consist of dense rocks, with few phenocrysts, composed of labradorite laths with interstitial augite. Some of the nonporphyritic rock contains a little olivine. The basalts are less intensely altered than the andesites.

Long, narrow dikes of basalt stand up here and there as ridges. The basalt of the dikes is so much fresher than that of the flows as to suggest that it may be considerably younger. There are also irregular masses of comparatively coarse-grained basalt like that at the Red King prospect (pl. 44). Some of these are clearly intrusive, but some of the basalt flows are so coarse as to be indistinguishable from intruslve bodies whoro 
exposures are poor. Only the more consplcuous dikes in the vicinity of areas that have been studied in detall are represented on plate 39. Some of the exceptionally porphyritic andesite in the mineralized reefs has such irregular outlines as to suggest that it also may be intrusive, though similarly porphyritic rock near some of the reefs seems clearly to be effusive lava.

Sillcic lavas were recognized south of the Horse Heaven prospect in only two places, one at the Flsher prospect and the other near the center of T. 40 S., R. 35 E., though they probably are present in other parts of the Pueblo Mountains also. At the Flsher prospect there are at least two flows of dacite, interstratifled with andesitic flows. The lsolated exposure near the main road in T. 40 S., R. 35 E. probably consists mainly of rhyolite but includes some tuff.

Age.--The silicic rocks represented by outcrops near the Steens Mountain prospect are probably the oldest Tertiary rocks in the region. The dominantly andesitic flows along the eastern side of the mountains, particularly along the upland bench from Flelds Creek to Arlzona Creek, are next younger and probably correspond roughly to the steens Mountain andesitic series of Fuller. The flows that form the main crests of both mountain ranges are stratigraphically still higher and probably correspond in a general way to the steens basalt.

No fossils are known to occur in the volcanic rocks within the area of plate 39, and few have been reported from nelghboring areas. Fuller $8 /$ found leaves that he regarded as of middle Miocene age in beds thought to be older than any here described, and stated that his Steens Mountain basalt was erupted either late in the Mlocene or early in the Pliocene. The conclusion that the volcanic rocks here described are mainly of Mlocene age

g/ Tuler, R. 8., op. c1t., pp. 43, 51-52, 115. 
Is in accord with such facts as are known regarding simliar rocks in neighboring regions. $9 /$

\section{older alluvium}

The easterly spurs of the mountains from the southeast corner of T. 37 S., R. $323 / 4$ E. to southeast of the center of $T$. $40 \mathrm{~S} .$, R. 35 E. are composed of material that has the essential characteristics of alluvial deposits but has been compacted, uplifted, and both flexed and faulted. It consists largely of coarse, subrounded to angular sand. but contains also much gravel, most of which is rather poorly rounded and sorted. On the lower northeast slopes of Pueblo Mountain the formation includes a heterogeneous assemblage of gravel and boulders that could only have been deposited by floods or torrential stréams. In a few places, small masses of compact silicious sinter appear to be interbedded with the sand. The formation has obviously been derlved from the erosion of the rocks described above, for it includes representatives of the different andesitic and basaltic lavas and, in its southern part, of the metamorphic rocks as well. The material is compacted and somewhat cemented. Its bedding is indistinct in most places, but exceptionaliy good exposures in widely scattered places show that it is inclined at angles up to $35^{\circ}$. The tilting and the extensive erosion this older alluvium has undergone distinguish it from the coarse parts of the Quaternary alluvial deposits, which it otherwise resembles.

The older alluvium rests on the dominantly andesitic beds at the eastern edge of the upland bench. In some exposures there is a small angular unconformity between the two, in others both formations are horizontal. The only fossil remains that have been found in this alluvium are two fragments of a silicifled

2/ Maccinitie, H. D.. The Trout Creek flore of southeastern Oregon: Carnegie Inst. Mashington Pub. 416, pp. 40-45. 1933. Plper, A. K., and others, op. c1t., pp. 49-51. 
bone, from an outcrop at the edge of the mountains north of Arlzona Creok. According to C. I. Gazin of the National Museum the fragments are "part of a metapodial of a large camelo1a or antilocaprine mamal". 10/ The bone gives little clue as to age, for Gazin remarks that "these types range through most of the later Tertiary". The relations of the older alluvium to other rocks suggest that it is of Pllocene age.

\section{Quaternary alluvlum}

Alvord Valley is floored with sand and silt, which grade into the coarser materials forming the alluvial cones along its margins. The finer deposits are thought to have been laid down mainly in Plelstocene and later lakes. There has been some redistribution of material by wind, but in the area represented by plate 39 the amount so moved has been small. The streamways in the mountains are lined with shallow deposits of silt, sand, and gravel. The outer spurs and foothills in some places have thin mantles of unconsolidated gravel.

\section{$\underline{\text { Structure }}$}

Both the volcanic rocks and the older, compacted alluvial deposits have been folded. The Steens and Pueblo ranges are on the western flank of a broad dome which appears to have extended across the site of Alvord Valley. The prevalent dip of the volcanic rocks throughout the Pueblo Mountains is westerly at low to moderate angles, though in a few places the dip exceeds $45^{\circ}$. The dip and strike symbols on plate 39 that do not give the angle of dip are based on distant observations or on alrplane photographs. The dome is complicated by local anticlines such as the irregular fold in the neighborhood of the Rabbit Hole and Red King prospects. East of these prospects the older alluvium

10/ Gazin, C. I., personal communication. 
dips west for most of the extent of 1ts exposure, aithough commonly at lower angles than the lava. Over large areas the alluvium lies nearly flat. Farther south, however, as shown on plate 39, the dips in the older alluvium are diverse, and locally as steep as $35^{\circ} \mathrm{NW}$.

The flexed rocks are broken by moderately complex faulting. The scattered observations made during the present study are in accord with the view $11 /$ generally held that the faults are normal. Smith, $12 /$ however, has argued that the faults are reverse.

As detalled studies during the present investigation were confined to the immediate vicinity of prospects, the major faults have not been mapped. Fuller $13 /$ mentions a number of step faults in the steens Mountains. He thinks that the high range crest west of Andrews results from a major fault that strikes N. $20^{\circ} \mathrm{E}$. , dips east, and merges with one of northerly trend along Wild Horse Creek. The faults mapped at the Fisher prospect (see pls. 39 and 41) coupled with the topography in this part of the range, indicate the presence of major faults that strike about $N .20^{\circ} \mathrm{W}$. and in part dip southwest. The long northeastward-striking dikes of fresh basalt, scattered along the east flanks of both ranges, seem to be in fissures complementary to these fault fissures.

Fuller's inference that the topographic depression between the steens and Pueblo ranges results from transverse faults is strengthened by the presence of fractures that have an average trend of $\mathrm{N}$. $50^{\circ} \mathrm{W}$. In the ridges near Pedro Ranch and by the form of the main ridges in and near the southern part of

11/ Russell. I. C.. A geological reconnalssance in southern Oregon: o. s. Gool. Survey 4 th Ann. Rept., pp. 438-440; 442-445, 1884. Naring, G. A., op. clt.. pp. 24-26, p1. 3.

ruller, R. B.. and Maters, A. C.. The nature and origin of the horst and graben structure of southern Oregon: Jour. Geology, vol. 37. pp. 204-238, 1929.

Tuller, R. E., op. c1t., pp. 1-130.

12/ Snlth, T. D., Contribution to the geology of southeastern Oregon (Steens and Pueblo Mountains): Jour. Geology, v01. 36, pp. 422-440, 1927. 13/ Raller, R. E., op. c1t., pp. 25-36. 
T. 37 S., R. $323 / 4$ E. and the northwestern part of T. 38 S., R. $34 \mathrm{E}$. The zone of transverse faults may extend from near Alvord Peak to south of Fields triangulation station.

The main faults on the eastern slopes of the Pueblo Mountains probably have an average trend of N. $20^{\circ}-30^{\circ} \mathrm{W}$. They may have a radiate pattern analogous to that of the minor fractures at the Rabbit Hole prospect.

As Davis $14 /$ has pointed out, the mountains have been so extensively eroded as to prove that the maln uplift is old. He regards the upland bench just east of the main ridge of the Pueblo Mountains as "a series of normal subsequent valleys--" and interprets the southern part of the steens Mountains as "a block of base-leveled monoclinal mass, lifted and somewhat til.ted to the west and maturely eroded." Inspection of the ground, with the ald of alrplane photographs, results in conclusions broadly similar to those of Davis. The upland bench is an old erosion surface with numerous cuesta-shaped monadnocks. Streams in the southern part of the Steens Mountains are bordered by imperfect berms which appear to record the continuation northward of the same erosion surface, less perfectly developed. Most of the transverse faults consplcuous in this part of the region probably antedate the old surface, but renewed movement on some of them may have contributed to the complexity of the topography. The deposits of older alluvium that form the foothills from Pueblo Mountain to north of Fields probably const1tute the waste from the old erosion surface and were uplifted with 1t. These foothills swing in a shallow arc, jagged in detall, along the border of Alvord Valley.

The bluffs at the valley end of most of the spurs have been cut or modified by wave action in the lake that filled Alvord Valley in Pleistocene time. 15 In places the bluffs are so

14/ Dav1s, T. M., The mountaln ranges of the Great Basin: Goographical essas:, pp. 760-768, 1920.

15/ Russe11, I. C., op. c1t., p. 458. 
straight as to suggest that they resulted from fault movements of comparatively recent date. This stralghtness is best exemplified in the line of bluffs, about $2 \frac{1}{2}$ miles long and striking about $\mathrm{N} .53^{\circ}$ W., through which Willow and Cottonwood creeks reach the plain.

\section{QUICKSILVER DEPOSITS}

The presence of metal minerals in the Steens and Pueblo mountain ranges has long been known, but the deposits have received Iittle attention except for desultory prospecting, mainiy by the local stock ranchers. Quicksilver, the principal metal sought, is reported to have been discovered over 40 jears ago, yet the total production of quicksilver from the two mountain ranges through 1940 has probably been less than 10 flasks. There has been some mining for gold and copper, especially in the southern Pueblo Mountains, where a little gold has been produced.

The metal deposits are of three kinds. In one, represented by the Steens Mountain prospect, the cinnabar is along fractures in widely silicified rhyolitic rock. The second kind, to which most of the numerous deposits near fields belong, consists of long, narrow siliclfled zones or reefs in volcanic rock, containing mercurial tetrahedrite, cinnabar, and subordinate amounts of other minerals. The third kind, on and near Pueblo Mountain, is in 1rregular fracture zones in metamorphic rock. These fracture zones have been worked malnly for their gold content, but they also contain chalcopyrite, tetrahedrite, and other sulfides, inçluding some cinnabar in places.

\section{Mineralogy}

The lodes contain mercurial tetrahedrite, cinnabar, pyrite, chalcopyrite and other copper sulfides, galena, magnetite and other iron oxides, quartz, barite, clay, and oxidized copper 
minerals. The sheared rock of the lodes in the Tertiary lavas is so intensely altered that original constituents rarely remain. In the metamorphic rocks of Pueblo Mountain and its vicinity the original rock minerals are not so thoroughly altered.

Mercurial tetrahedrite $\left(5 \mathrm{Cu}_{2} \mathrm{~S} .2(\mathrm{Cu}, \mathrm{Fe}, \mathrm{Zn}, \mathrm{Hg}) \mathrm{S} .2 \mathrm{Sb}_{2} \mathrm{~S}_{3}\right)$, with so large a proportion of arsenic as to approach mercurial tennantite $\left(5 \mathrm{Cu}_{2} \mathrm{~S} .2(\mathrm{Cu}, \mathrm{Fe}, \mathrm{Zn}, \mathrm{Hg}) \mathrm{S} .2 \mathrm{As}_{2} \mathrm{~S}_{3}\right)$ in composition, is the distinctive mineral of most of the lodes. This mineral is widespread but rarely abundant, and in most of the present exposures It is altered. A partial analysis of tetrahedrite plcked out of a specimen from the retort dump at the Rabbit Hole Prospect has been made by J. J. Fahey of the Geological Survey. The specimen is exceptionaliy rich and fresh, but like all materlal obtainable from the shallow workings in the district, it is somewhat weathered and slightly contaminated by supergene minerals. Among these chalcocite, covellite, and bornite are recognizable. Traces of cinnabar are also present. The specimen was used up in the chemical work done.

Analysis of tetrahedrite from the Rabbit Hole prospect [J. J. Fahey, analyst]

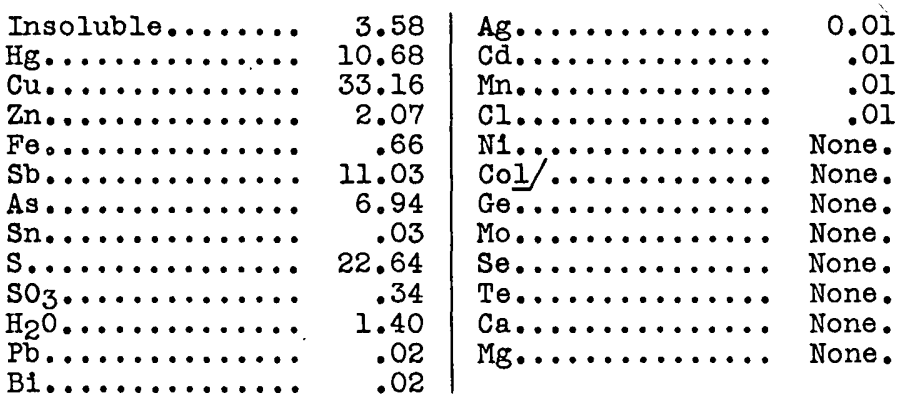

\section{If Determined spectrographlcally by Goorge Stelger.}

The analysis indicates that the tetrahedrite contains only a little more than 10 percent of quicksilver, whereas cinnabar contains 86 percent. Even so, rock in which such tetrahedrite is so finely disseminated or so masked by oxidized products as 
to be difficult to see might nevertheless be ore. This fact should be borne in mind by prospectors who might otherwise let the conspicuously colored oxidized copper minerals lead them to overlook the quicksilver content of lodes of this kind.

The fact that tetrahedrite is one of the principal quicksilver minerals in the district may necessitate special metallurgical treatment, for there is danger that antimony and arsen1c compounds from the tetrahedrite may pass into the condensers and contaminate the quicksilver. $16 /$ inc, which is also present, is another metal that is reported 17 to complicate treatment of quicksilver ore, but the analysis indicates that the quantity of zinc is too small to be significant. Lodes in the metamorphic rock of Pueblo Mountain contain tetrahedrite, but it is not known whether this mineral is mercurial, for the material obtained was so altered that it could not be determined whether its quicksilver content is confined to the cinnabar.

Cinnabar (HgS) is the only quicksilver mineral recognized in the deposits at the Steens Mountain prospect, and 1t is present. in most of the other prospects. Some is distinctly crystaline, but much of it is compact and earthy, and, where untarnished, comparatively light-colored. In some places cinnabar grains are scattered through the altered lava at some distance from the lodes, mainly in interstices between the grains in the rock. Where tetrahedrite and cinnabar occur together, the cinnabar commonly cuts or coats the tetrahedrite. In places on the Fisher group cinnabar appears to coat malachite. In places, especially on Pueblo Mountain, earthy cinnabar is mingled with Iron oxides. Analyses show that a little mercurlc chloride is associated with the cinnabar, but no chloride minerals have been recognized and it is doubtful whether enough chloride is present to materially affect the treatment of the ore.

16/ Duschak, L. B., and Schuette, C. N., The metallurey of quickstlrer: J. S. Bur. Mines Bull. 222, pp. 16-17, 1925.

17f Gould, Benry, personal communication. 
Some pyrite $\left(\mathrm{FeS}_{2}\right)$ is probably present in most parts of the lodes, but only in small grains. Chalcopyrite $\left(\mathrm{Cu}_{2} \mathrm{~S}_{\circ} \mathrm{Fe}_{2} \mathrm{~S}_{3}\right)$ is - locally abundant in lodes in the metamorphic rocks of Pueblo Mountain, but in the Tertiary rocks it is nowhere abundent and Is commonly absent. Galena ( $\mathrm{PbS}$ ) has been recognized only in ore from the Blue Bull prospect. A little bornite $\left(\mathrm{Cu}_{3} \mathrm{FeS}_{3}\right)$, chalcocite $\left(\mathrm{Cu}_{2} \mathrm{~S}\right)$, and covellite (CuS), accompany the tetrahedrite and probably the chalcopyrite, but these minerals are rarely plentiful enough to be recognized in the fleld. Such oxldized copper minerals, including malachite $\left(2 \mathrm{CuO} \cdot \mathrm{CO}_{2} \cdot \mathrm{H}_{2} \mathrm{O}\right)$, azurite $\left(3 \mathrm{CuO} \cdot 2 \mathrm{CO}_{2} \cdot \mathrm{H}_{2} \mathrm{O}\right)$, chrysocolla $\left(\mathrm{CuO} \cdot \mathrm{SIO}_{2} \cdot \mathrm{nH}_{2} \mathrm{O}\right)$, and tenorite (CuO), make conspicuous splashes of color on most exposures of the lodes but are nowhere present in large quantities.

Several different iron-oxide minerals are widely but sparsely distributed throughout the altered lava that forms the wall rock of most of the lodes. These include magnetite $\left(\mathrm{Fe}_{3} \mathrm{O}_{4}\right)$, and probably both hematite $\left(\mathrm{Fe}_{2} \mathrm{O}_{3}\right)$ and different forms of limonite (hydrated iron oxides). As leucoxene appears to be present the magnetite probably contains some titanium. Aggregates of the Iron-oxide minerals, mixed with clay minerals, rim and replace the constituents of the original rock in such a way as to indicate that they are of hydrothermal origin. Those parts of the lodes that have ferruginous sulfides and carbonates as original constituents contain such weathering products as earthy hematite and limonite in the present exposures.

Quartz is finely disseminated through much of the altered lava in the walls of the lodes. It is abundant in the altered rock and forms numerous cherty veinlets in those parts of the lodes that are hard enough to stand in rellef. At the steens Mountain prospect the country rock is thoroughly Impregnated with fine-grained quartz, and in the ore zones there are bands of quartz crystals with earthy cinnabar molded on them. Most of the quartz in the lodes in metamorphic rock is coarse and has a 
glassy luster, so that it differs sharply in appearance from the dull-white, fine-grained quartz in the Tertiary rocks.

Barite $\left(\mathrm{BaSO}_{4}\right)$ forms crystalline crusts in some of the lodes. especially on and near the Rabbit Hole and Fisher properties, but is nowhere abundant.

Calcite $\left(\mathrm{CaCO}_{3}\right)$, at least in part ferruginous, is fairly widespread in the altered lava in the walls of the lodes, and forms gash veins in several places. On and near the Blue Boy claim there are large veins of fermiginous calcite.

Clay minerals are plentiful in the altered lava. Kaolinite $\left(\mathrm{Al}_{2} \mathrm{O}_{3} \cdot 2 \mathrm{~S}_{2} \mathrm{O}_{2} \cdot 2 \mathrm{H}_{2} \mathrm{O}\right)$ is probably the most abundant of these, but hydro-micas and nontronite $\left((\mathrm{Fe}, \mathrm{Al})_{2} \mathrm{O}_{3} \cdot 2 \mathrm{~S} \mathrm{O}_{2} \cdot 2 \mathrm{H}_{2} \mathrm{O}\right)$ are locally abundant. Small amounts of other clay minerals are locally present.

\section{The lodes}

The deposits at the Steens Mountain prospect (pp. 249-250) consist of compound fracture zones in thoroughly sillcifled rhyolitic rock. Closely spaced, subparallel parting planes are cut by longer but more irregular fissures, and both are locally accompanied by cinnabar. Outcrops are inconspicuous and the results of the little development so far done suggest that individual ore shoots are so small and irregular that blocking out any large tonnage would probably be difficult. On the other hand the ore is relatively rich and consists so largely of cinnabar and quartz as to present no metallurgical problems. It contains no tetrahedrite.

The lodes in most of the prospects in the southern steens and northern Pueblo mountalns are different from these. Here the volcanic rocks are more or less thoroughly altered over wide areas. Within these areas there are mineralized fracture zones, many of which are hard enough to form ralsed ribs, locally over 10 feet high. Many of the mineralized fractures are reefs that 
persist from one to several thousand feet and have widths up to 20 feet, locally more. These reefs form groups that are eas1ly traceable for long distances. One such group, which includes those of the Rabbit Hole property (pls. 39 and 44), is certainly over 2 miles long. The ground between the Rabbit Hole and Blue Bull was not studied during this investigation, but it contains projecting siliceous reefs that are visible from a distance, and the mile and a half between the two prospects should probably be added, therefore, to the length of the group of reefs. The width of the group exceeds half a mile in places. Both to the north and south the ground in which possible extensions may 110 is at least in part buried beneath the older alluvium.

The group of reefs that includes those of the Lucky strike property is well over a mile and a half long, and the branch to the north that crosses Crimson Rose ground may extend considerably beyond the reefs plotted on plate 43 . The sillclfled zones on Lucky Strike ground (see pl. 42) are broader and less riblike than most, but it is only in certain of the more thoroughly fractured parts of these that cinnabar is reported to occur.

The reefs of the Flsher group (see pl. 4l) have exceptionalIy diverse trends. One reef is a thick breccla zone that is a prominent feature of the topography and is essentially continuous for about a mile, but most of the quicksilver so far found is in the shorter reefs, none of which are more than a few feet wide, near the northeast end of the group. These do not project as consplcuously above the surrounding hill slopes as many of those farther south. There are prospect pits north of the hill occupled by the Flsher group, and the reefs may continue farther in that direction than is indicated on plate 41.

The reefs consist largely of altered lava, which differs from that outside the reefs in belng more thoroughly altered and In containing a larger proportion of fine-grained, added quartz. The altered rock is shot through with velnlets of quartz, many 
of which follow fractures approximately parallel to the reefs. The material of the reefs is rudely banded, mainly because of differences in the intensity of alteration along such fissures. Tetrahedrite, cinnabar, and minor amounts of other sulfides, together with some barlte and calcite, are scattered through the reefs. Alteration products of the metal minerals color the material of the reefs in patches.

The apparently discontinuous quartz lenses and silicified shear and breccia zones in the metamorphic rocks near Pueblo Mountain constitute a third variety of lode. Some of these contain enough gold to be mined for this metal. All contain some copper, mainly in chalcopyrite and tetrahedrite, but the average copper tenor is rather low and no record of the production of any copper is available. Some cinnabar is present, in part mingled with alteration products of the copper minerals. A few hundred pounds of the cinnabar ore is reported to have been mined and treated. The lodes have some resemblance to the more extensively developed lodes of the sumpter quadrangle, in and near Baker County, Oregon, some of which contain mercurial and

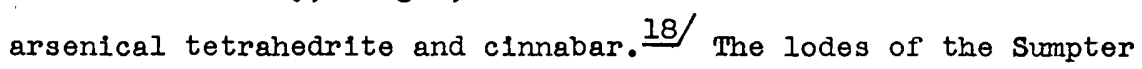
area are probably of Mesozolc age, and it may be that those in the metamorphic rocks of the Pueblo Mountains are also Mesozo1c, although the others, in the volcanic rocks, are obviousiy not older than Mlocene.

\section{Origin}

The present ore deposits result from a succession of hydrothermal processes. The lodes in the metamorphic rocks probably were formed long before Tertiary volcanism began, and it is possible that the cinnabar in them has been added by solutions that

18/ Indgren, Waldemar, The gold belt of the Blue Mountalns of Oregon: U. S. Geol. Survey 22d Ann. Rept., pt. 2, pp. 599-697, 1901.

Pardee, J. T., and Hewett, D. Y., GeologJ and mineral resources of the Sumpter quadrangle: Mineral Bosources of Oregon, vo1. 1, 110. 6, pp. 5066. 1914. 
c1rculated along the old, mineralized fracture zones in Tertiary time. At a late stage in the volcanic activity widespread hydrothermal alteration of the lava obliterated most of the orig1nal magmatic minerals over considerable areas. Changes of this kind were especially intense in certain areas containing fracture zones, which may have alded in the clrculation of the solutions. The rock of the fracture zones was more thoroughly si-. licifled than the rest, and the fractures were fllled with quartz and other minerals, of which mercurial tetrahedrite was the principal valuable mineral, except in a few instances. Much of the cinnabar that accompanies the tetrahedrite is later than that mineral. Possibly part of it is a result of redistribution by surficial waters of quicksilver released from the tetrahedrite by weathering. Presumably part of the cinnabar in all of the lodes, and most or all of that in lodes of the kind represented by the Steens Mountain prospect, is original.

\section{$\underline{\text { Outlook }}$}

The district contains no blocked-out ore reserves and very little ore in sight. Large parts of the lodes probably average as little as 3 pounds of quicksilver to the ton or less. On the other hand, the quantity of mineralized material is great. Quicksilver lodes are known at intervals for a distance of about 30 miles along the eastern flanks of the two ranges; many of these reefs are large and closely spaced, and several pockets of rich ore have been found in them.

Exploration so far has been limited and haphazard. Most of those engaged in it have had little experience and training in quicksilver mining and have lacked equipment and capital. The district is not well-adapted to development under these circumstances, partly because ore bodies that could be profitably worked by a few men with retorts appear to be both rare and small. Deposits like those of the Steens Mountain prospect may 
prove amenable to small-scale operations, but such deposits have thus far been found only at the north end of the district. The possible metallurgical difficulties mentioned on page 242 may also be a handicap to operators that are inadequately equipped. Nevertheless the large size and wide distribution of the lodes appear to warrant further exploration, and to hold out some hope that more extensive underground exploration may expose large ore bodies of low to moderate tenor.

Presumably the richer ore bodies will be found in zones of especially extensive fracture, mostly in the bodies here termed reefs. Possibly the apparent scarcity of quicksilver in the great breccia zone on the Fisher ground, in contrast to the relatively rich ore in the much smaller and less consplcuous fracture zones farther east, is typical. That 1s, the larger and more intensely silicified reefs may prove to be leaner than some of the smaller fracture zones, which were less effectively sealed with quartz. Most of the present prospect holes that show cinnabar are in the less thoroughly silicified parts of the reefs or in the kaolinized rock along the walls. In places cinnabar is disseminated in the wall rocks for scores of feet beyond the reefs and fracture zones. So far as present development shows, the tenor of this material is too low to be of value, but the possibility that some parts of the altered wall rocks contain enough quicksilver to be mined should not be overlooked.

In most quicksilver districts the cinnabar is so largely primary that secondary enrichment is not of economic importance. Here, however, conversion of tetrahedrite to cinnabar, with its higher quicksilver content, may have produced rich pockets that are confined to the shallow depths in which surface water has circulated. The cinnabar in the lodes of the sumpter region that contain mercurial tetrahedrite has been similarly explained. $19 /$ on the other hand, the reefs are so long as to sug-

19/ Pardee, J. T., and Hewett, D. F., op. c1t., pp. 65-66. 
gest that they persist to considerable depths. As tetrahedrite is a mineral that is commonly found in relatively deep-seated deposits, 1ts presence here suggests that the lodes of this region may persist to greater depths than is usual in deposits in which cinnabar is the principal ore mineral. In a few places, notably on Pueblo Mountain, there may be enough copper and gold to be of value, if only as a byproduct of mining for quicksilver.

\section{PROSPECTS}

The information gathered about each of the prospects visited In the sumer of 1940 is summarlzed below, approximately in order from north to south. Information on ownership and history was furnished principally by C. M. Doan, the postmaster at Flelds; some was gleaned from claim notices. About 17 groups of claims scattered along the eastern front of the steens and PuebIo ranges were visited. Most of the principal prospects are within 5 miles of Fields. A few scattered prospects were not visited.

\section{Steens Mountain prospect}

A deposit on the east slope of the middle part of the steens Mountains near the western border of T. 34 S., R. 34 E., and southeast of the peak of steens Mountain, is known as the steens Mountain prospect. It was discovered in the sumer of 1939 by John Stephenson. In 1939 and 1940 1t was operated by the Horse Heaven Mines, Inc. In November 1940, the property was returned to the original owners, Glenn stephenson; R.A.O. Officer, and Bert Roark. At that time there was about 60 tons of ore of an. average tenor of 1.5 percent of quicksilver on the dump. $\frac{20 /}{0 t h-}$ er deposits are reported to have been discovered a short distance to the southwest. 
The prospect is in highly silicifled and kaolinized rhyolitic lava, which is in part sheeted by closely spaced, parallel fracture planes. The principal development is in the branching tunnel shown in plate 40 , but there are also a number of surface trenches, some of which show cinnabar. The tunnel has an aggregate length of about 270 feet and contains two shallow winzes and a small underhand stope. It discloses three fissure zones each of which contains considerable cinnabar. A small sample chipped across a width of 8 inches in the fracture zone on the west side contalned 4.63 percent of quicksilver and 0.21 percent of mercuric chloride. The work in 1939 is reported to have resulted in mining, close to the portal of the tunnel, about 1,800 pounds of ore from which 6 flasks of quicksilver were obtained. While this body of exceedingly high-grade ore was very small, its presence encourages the hope that other rich ore shoots exist in the vicinity.

\section{F1sher group}

The deposits of the Fisher group, in the southwest part of T. 36 S., R. 33 E., were discovered by Clay T. Fisher. The six claims of this group and the three claims of the adjacent Regal group are owned by M. M. Doan and members of his family and are here considered together. In February 1941, they were under option to Carl Olsen of Seattle, Washington. At intervals through 1939 and 1940 several pits a few inches to a few feet deep and one tunnel 30 feet long had been dug. In september 1940, about a ton and a half of selected ore was taken from one of the pits and carried to the retort at the Rabbit Hole prospect. According to $C$. M. Doan it ylelded about 20 pounds of quicksilver.

The Fisher and Regal clalms occupy a wedge-shaped hill at the edge of the mountains (pl. 41). This hill is composed main ly of porphyritic andesitic lava that in general lies nearly horizontal. West of it a basalt dike strikes about N. $20^{\circ} \mathrm{E}$. 


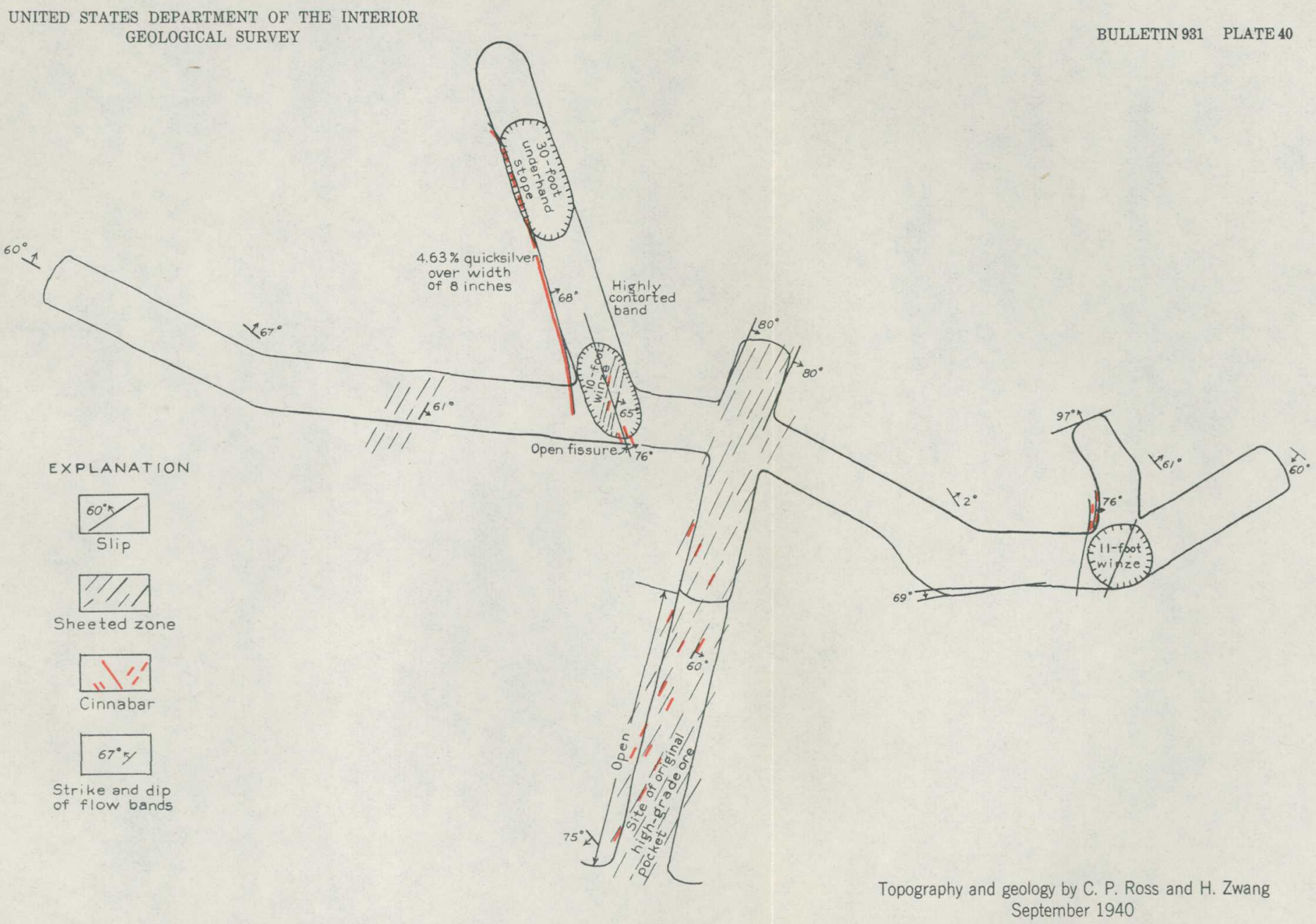

GEOLOGIC SKETCH MAP OF THE TUNNEL AT THE STEENS MOUNTAIN PROSPECT

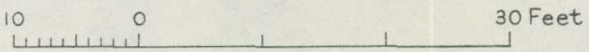




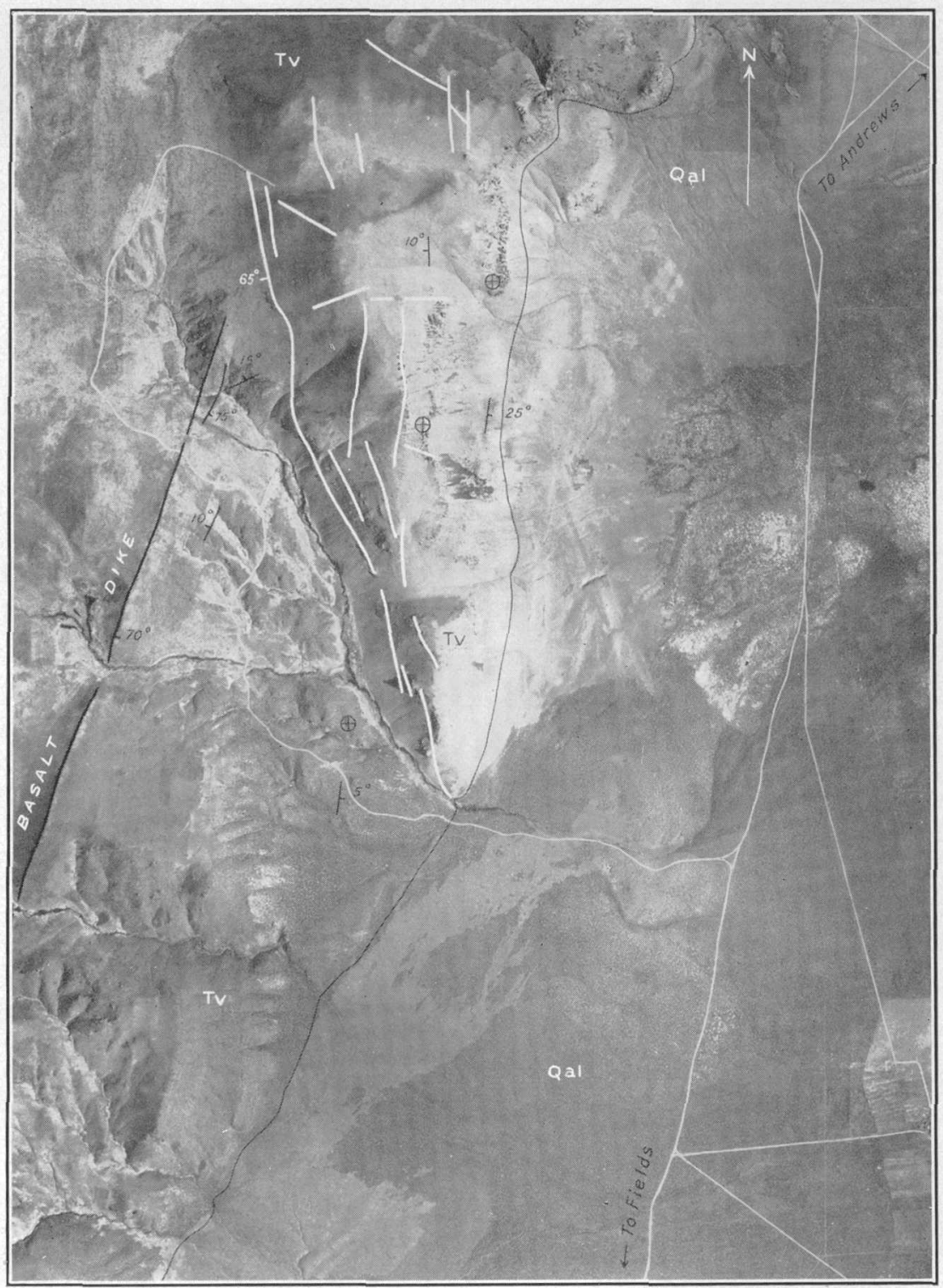

THE LODES OF THE FISHER GROUP.

Traced in September 1940 by C. P. Ross. Scale, approximately 1:24,000. Qal, Quaternary alluvium; Tv, Tertiary volcanic rocks; $\oplus$ horizontal beds; white lines indicate silicified zones. 
through flows of amygdalo1dal andesite. A conspicuous silic1fled fault breccia that dips southwest extends along the southwest side of the hill. This breccla is so closely in line with a series of topographic depressions which extend far to the northwest as to suggest that it is part of a large fault zone. No direct evidence of faulting was noted on the east side of the h1ll, but this side is so stralght and steep as to suggest that 1t may be bounded by a fault with downthrow on the valley side. If so, the silicified zones mapped on plate 41 mark fractures within a wedge-shaped fault block between masses that are downthrown on both sides of 1t. So far most of the work on the group has been done at the north end of the hill, where most of the pits in the silicifled fracture zones show copper-stained rock with some tetrahedrite, and many of them also show cinnabar. Barite crystals are conspicuous in places. The silicified zones. of diverse trends which extend all over the hill are so similar to those that have ylelded cinnabar that all might be expected to contain this mineral in places. A little cinnabar has been found disseminated in lava some distance from any of the obviously mineralized fractures.

\section{Lucky Strike and adjacent prospects}

A line of prospect holes follows a series of silicified reefs along the ridges across T. 37 S., R. $323 / 4$ E. from southeast of Pedro Ranch to the eastern edge of the high mountains. The distance is about $2 \mathrm{miles}$ in a N. $50^{\circ} \mathrm{W}$. direction, and the zone has a maximum width of nearly three-fourths of a mile north of the ranch bulldings. According to C. M. Doan, the ground along the northeast side'of the southeast part of the zone was originally staked in 1929, because of the gold found in some of the lodes, by Pete Cachenaut and Ora and Robert Doan. No work was beling done here in the summer of 1940 . 
Some of the gold prospects are included in the Blue Boy claim, which according to a claim notice was located January 17, 1929, by Olive W. Doan, C. Sturgeon, and R. E. Doan. Claim notices Indicate that the Crimson Rose group of five claims, 10cated by members of the Doan family, lies northwest of the Blue Boy. The hill between the Blue Boy clalm and the deserted buildings of the Pedro ranch is occupied by the seven claims of the Lucky Strike group, staked in 1933 by M. M. Doan and assoc1ates. Part of this ground was staked in 1931 by Tom Dufferena and associates but is reported to be no longer claimed by them. The Lucky strike group is joined on the northwest by the four claims of the Mogul group, staked in 1939 by C. M. Doan. Northwest of the Mogul group are six claims held by R. E. and B. J. Blalr since 1933, and beyond these are four claims located by Ben O'Keefe in December 1931. The approximate position of most of the Lucky Strike claims is evident from marked claim stakes, but the boundaries of the claims in other groups were not learned.

The Blue Boy claims and adfacent ground, on the nose of a ridge immediately northeast of Lucky Strike claim No. 5, contain a tunnel 120 feet long, a shaft 40 feet deep, and several cuts and pits. The lodes in places contain visible cinnabar. Four of the samples cut here gave negative results on assay, but one from the shaft contained 0.01 percent of quicksilver, and refined tests show that the others contain the metal in very small quantities. Tests for gold were not made during the present investigation, but several assays are reported to show a range of $\$ 7$ to $\$ 29$ a ton in gold (presumably at $\$ 35$ an ounce). The ridge on which the Blue Boy lies is composed malnly of andesite. A conspicuous silicified rib follows the nose of the ridge down to creek level (pl, 42). This rib strikes about $N_{0} 15^{\circ} \mathrm{W}$ and stands nearly vertical, but in places it dips steeply east. As the lava on opposite sides differs in appearance, attitude, and 
extent of alteration, the rib probably marks a fault of considerable displacement. On the ridge top the $\mathrm{rib}$ is crossed by thin veins of calcareous tufa that strike east and alp about $35^{\circ}$ S. Much of the lava on the southwest slope of the ridge is markedly altered but does not contain enough silica to be highly resistant to erosion or to have wholly obliterated the original texture. This altered material is cut by numerous veins of musty calcite, most of which strike north of west (pl. 42). On plate 43 , the principal calcite veins are shown, but, in order to avold confusion, the broad area of partiy silicified ground on the Blue Boy is not.

The ridge just described is a branch of a larger ridge, the adjacent part of which contains the Crimson Rose claims. The branches of this ridge northwest of the Blue Boy contain several silicifled reefs (see pl. 43), most of which stand in distinct relief. One is a continuation of the principal reef at the Blue Boy. The reefs contain sulfides in several places, and cinnabar is exposed in at least one place. Exploration has been confined to shallow pits. A basalt dike is also exposed.

The Lucky Strike group occuples a ridge between two low saddies. The ridge consists largely of amygdaloidal andesite with some basalt and other kinds of lava. Irregular zones of altered rock contain enough silica to stand in some rellef (pl. 42). Here and there within these are fractures of northwest trend. Shallow excavations on these are reported to have revealed some cinnabar in the rusty quartz. A long trench on Lucky Strike No. 3 explores a zone of calcite veins in basaltic lava near a basalt dike.

The Mogul group includes numerous, branching siliclfied zones (see pl. 43) that in several places contain quicksilver and copper minerals, and a basalt dike that probably cuts one of the silicifled zones. Small excavations are scattered over these claims. On the ridge crest on the Mogul No. 2 a short. 
shaft connects with a small irregular tunnel, from the floor of which extends a winze little more than 10 feet deep. On February 11, 1941, a new inclined shaft below the tunnel was reported to be 60 feet deep. 'The lode had not jet been reached in this shaft.

Two samples cut in the winze contained 0.12 and 0.05 percent of quicksilver. A sample from the shaft contained 0.03 percent of quicksilver. Most of the metal in this sample was in chloride. Some of the material in these workings contains so much cinnabar as to be obviously of higher tenor than the samples reported above. Both the shaft and the winze contain masses of porous chalky-white quartz, containing cinnabar, which differs in appearance from any of the other mineralized material seen in the district. Since this area was visited, exploration work has been resumed.

The silicified zones on Mogul ground become less conspicuous when they enter the Blair property. In the northwestern part of the Blalr property, however, a vertical reef that crops out on the crest of the ridge (see pl. 43) contains some exceptionally rich material, especially on the southwest side, where a tunnel 15 feet long and some pits have been opened. Samples from here' are reported to have ylelded several percent of quicksilver, but ore as rich as this was not found by the writer. One sample from a 4-inch band along a slip proved to contain 0.47 percent of quicksilver and a sample of the clay above this slip yielded 0.14 percent of quicksilver.

Northwest of the Blair claims mineralized ground was noted only on the o'Keefe No. 2 claim. Here pits and trenches disclose a vertical shear zone which contains some quartz and copper minerals. This zone is not resistant enough to stand in reIlef. 


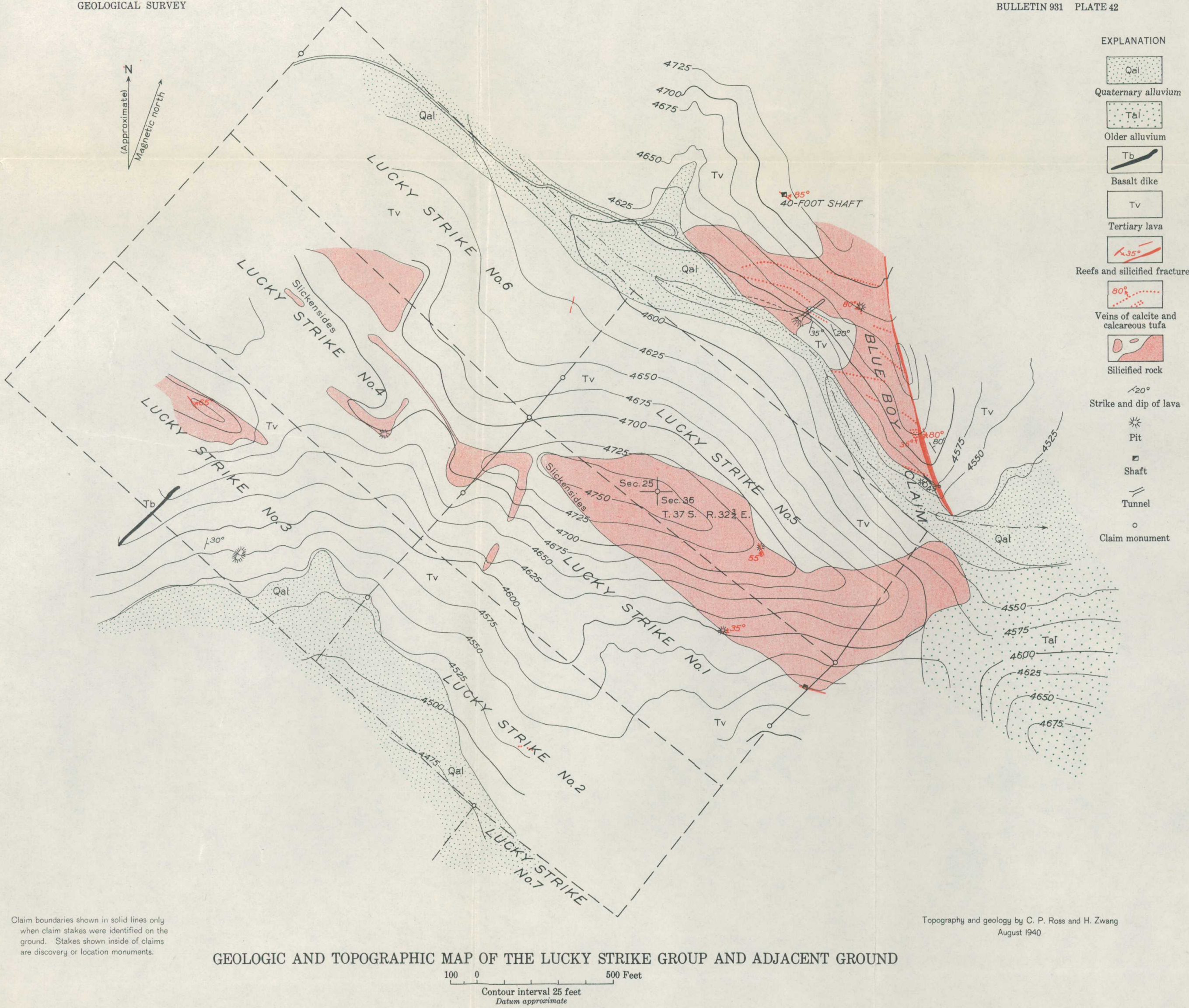




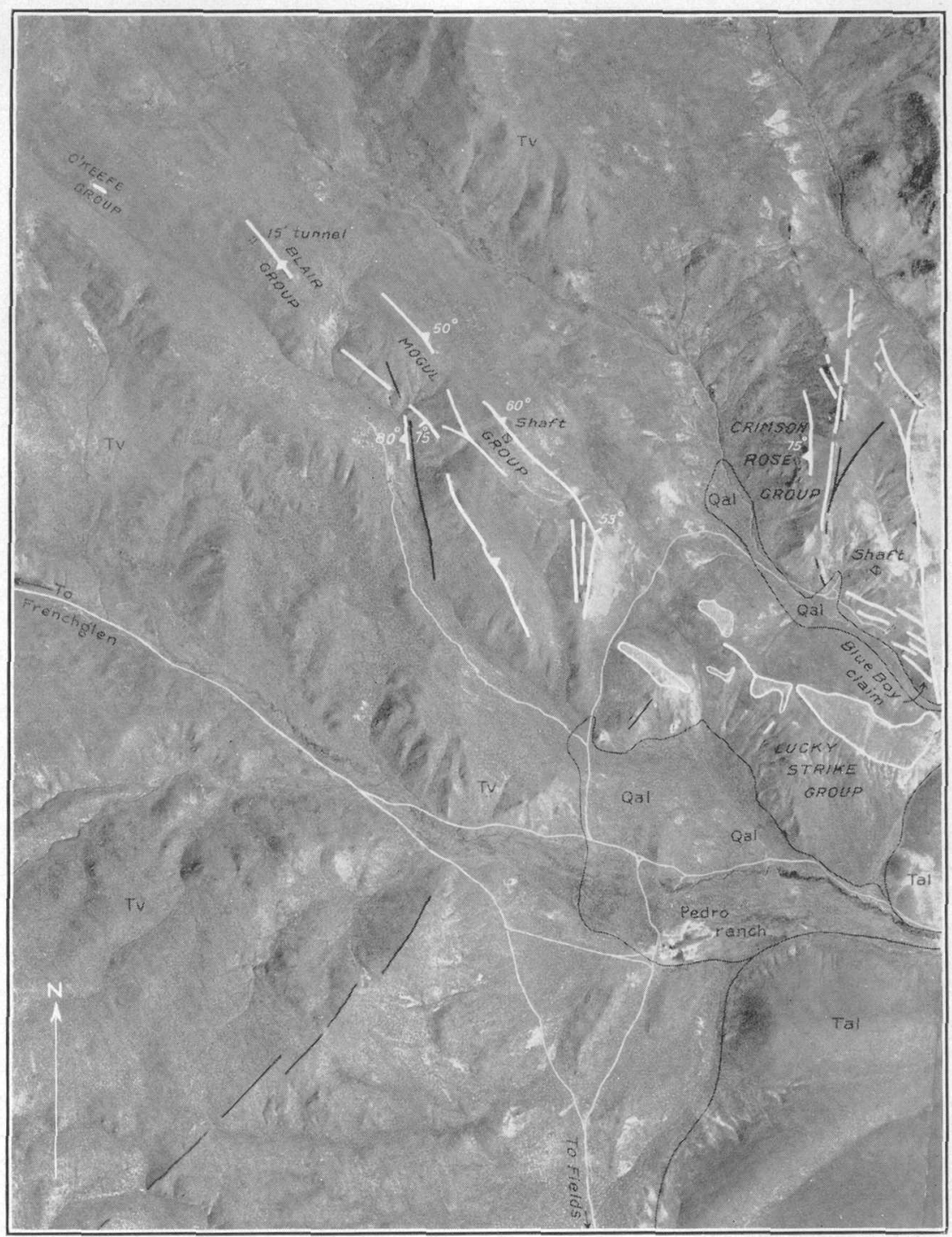

THE LODES OF THE MOGUL, BLAIR, AND O'KEEFE GROUPS AND ADJACENT GROUND.

Traced in September 1940 by C. P. Ross. Scale, approximately 1:24,000. Qal, Quaternary alluvium; Tal, older alluvium; Tv, Tertiary voleanic rocks; heavy black lines indicate basalt dikes; heavy white lines indicate silicified reefs and other veins; white areas are silicified zones. 


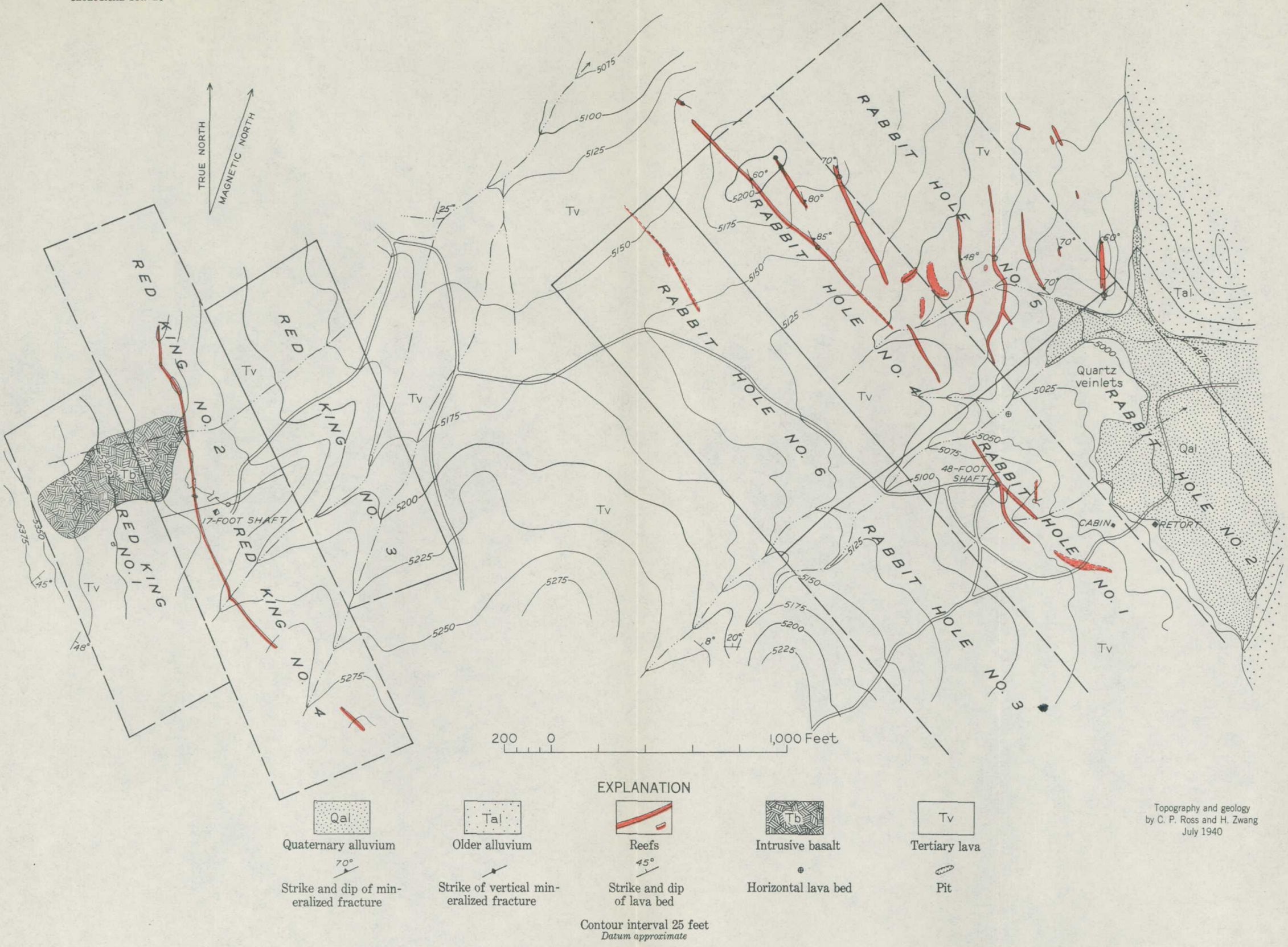




\section{Claims near Sesena Creek}

In the northeastern part of T. 39 S., R. 34 E., between Sesena Creek and the Red King and Rabbit Hole prospects, are several pits and short tunnels. Much of this ground was included in the Harmony group, located by C. M. Doan, but allowed to lapse. Early in September 1940, two claims in or close to sec. 2, T. 39 S., R. 34 E. were being worked by W. B. Stewart and Clay R. Fisher. These are called the Surprise group. When the property was visited a tunnel about 30 feet long had been driven in the older, tilted alluvium close to and nearly parallel with a silicified zone in the lava nearby. The hillside was strewn with numerous float pieces of quartz containing disseminated clnnabar, presumably from the silicified zone, and it is reported that cinnabar has since been found in place on this property. Some work was done in 1940 by Ben O'Keefe at a place roughly three-quarters of a mile west of the Surprise tunnel.

\section{The Red King group}

The Red King group of four clalms is in the east-central part of T. 39 S.,.R. 34 E. It was located in April 1939, by Glenn Stephenson, George Stephenson, Andrew Shull, and Bert Roark. This property contains a shaft 17 feet deep, a tunnel, and several pits and trenches (pl. 44). The tunnel is inclined and is filled with water to within a short distance from the portal. The princlpal lode on this property has been mapped for a distance of 1,800 feet, and extends beyond this to the northwest, though it is less clearly exposed there. An irregular mass of coarse basalt, believed to be intrusive, is exposed on the west side. The lode, which is several feet wide, consists of fractured, kaolinized, and somewhat siliclfied andesite. The andesite in the walls is intensely kaolinized for some distance beyond the material that is sufficlently sillcifled to stand in 
rellef. This lode does not form such prominent outcrops as those on the Rabblt Hole property. The main lode contains some pyrite, copper minerals, and cinnabar. The kaolinized wall rocks also contain cinnabar in places, but a sample from the bottom of the shaft in the wall rock contained no quicksilver.

\section{The Rabbit Hole group}

The Rabb1t Hole group of six claims, located in March 1940, by Robert Doan, lies east of the Red King prospect. It contains a small retort, a shaft 48 feet deep with a 30-foot drift to the weșt at its bottom, a tunnel 25 feet long, and many trenches and pits, some of which are 10 feet deep. Quicksilver was first found on these claims in 1929, and work has been done at intervals since then. Early in 1940 about a flask of quicksilver was retorted from between 3 and 4 tons of ore from the shaft and an equal amount from ore hauled in from nelghborlng properties.

The group is on the eastern flank of a local anticline in andesite and basalt flows with some clastic beds. It contains a system of siliceous reefs that radiate to the north and northwest and dip eastward (pl. 44). The shaft is at the junction of two of these, one of which is over 1,500 feet long. Several of the reefs are over 10 feet wide. Nearly all the excavations show copper stains, and in many of them tetrahedrite or cinnabar or both are visible. Barite is locally conspicuous. The selected ore that was retorted was moderately $\mathrm{rich}$, but the average tenor of the exposed material is low. A sample chipped from a 3-inch vein at the bottom of the shaft jielded only 0.01 percent of quicksilver on assay.

\section{The Blue Bull group}

The Blue Bull group of six claims is at the eastern edge of the upland bench between Horse and Willow Creeks, in the south- 
eastern part of T. 39 S., R. 34 E. M. M. Doan is the principal owner. The group contains a shaft 25 feet deep, at an inclination of $63^{\circ}$ along a vein. A crosscut at the bottom extends 35 feet northward. The outcrop at the shaft is inconspicuous, but 330 feet northwest is the southern end of a large silicious reef. A sample from a 2-1nch band at the top of the shaft was found to contain 0.99 percent of quicksilver and 0.07 percent of mercuric chloride. A sample chipped across a width of 2 feet on both sides of the shaft at a depth of 8 feet contained 0.01 percent of quicksilver. Both tetrahedrite and cinnabar are visible here, and in some narrow bands they are so abundant that several percent of quicksilver appears to be present.

There is reported to be a quicksilver prospect known as the Cash group on Willow Creek south of the Blue Bull. No work has been done there recently and the group was not visited.

\section{Arizona mine}

On the northwest side of upper Arlzona Creek, in the northwest corner of T. $40 \mathrm{~S}$, R. 35 E. there are extensive pits and trenches and a caved tunnel. A claim notice dated November 3 , 1934, signed by A. W. Van Riper, A. R. Wood, and William Grobe refers to the property as the Arizona mine. Much of the work here must have been done earlier than 1934.

The pits are in anclent quartzose sedimentary rocks and expose shatter zones with quartz, pyrite, and malachite. One of the better-defined fracture zones strikes N. $40^{\circ} \mathrm{E}$, and dips $40^{\circ}$ NW. It is reported that these workings were opened in the search for gold but that some quicksilver was also found in them.

\section{Prospects on Pueblo Mountain}

There are many pits, short tunnels, and shallow shafts high on the east slope of Pueblo Mountain in the western half of $T$. 40 S., R. 35 E. Most of these belong to the Pueblo and Farnham 
groups of claims. There are also prospect tunnels near Denio, but these were not studied. The presence of copper, gold, and quicksilver in this vicinity has been known for at least 25 years. The limits of the Pueblo and Farnham groups of claims are not known, but the workings of the Pueblo Gold Mining Co. center around the gold mill shown on plate 39, close to the end of the road in the southern part of the prospected ground. The tunnel at the mill is 260 feet long, and some of the caved workings farther north may once have been equally long. Small shipments of gold ore are reported to have been made from this property. A little work was done here in the summer of 1940.

The Farnham group is owned by E. D. Farnham, who has done intermittent prospecting there since about 1916. He says that he mined a few hundred pounds of high-grade quicksilver ore a few years ago, and that some of his workings contain considerable copper.

Both groups are in the Paleozo1c (?) metamorphic rocks and are on poorly defined fracture zones with widely different att1tudes. These zones have lentils of quartz and calcite with small quantities of pyrite, chalcopyrite, bornite, tetrahedrite, their oxidation products, and locally cinnabar.

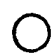


The use of the subjoined mailing label to return this report will be official business, and no postage stamps will be required

\section{UNITED STATES \\ DEPARTMENT OF THE INTERIOR}

GEOLOGICAL SURVEY

This label can be used only for returning official publications. The address must not be changed.

\section{GEOLOGICAL SURVEY,}

\section{WASHINGTON, D. C.}


Orton Memoriai Libray of Geology 180 Orion Hali, 155 S. Oval Mall The Ohio State University

Columbus, $\mathrm{OH} 43210$ 